Jurnal MAKSIPRENEUR, Vol. I, No. 2, 2012, hal. 1-16

\title{
KOMITMEN ORGANISASI, MOTIVASI KERJA DAN PERAN MANAJER PENGELOLAAN KEUANGAN DAERAH TERHADAP KINERJA MANAJERIAL SATUAN KERJA PERANGKAT DAERAH DI KABUPATEN MAGELANG
}

\author{
Muji Mranani \& Intan Dwi Karyati \\ Universitas Muhammadiyah Magelang, Magelang
}

\begin{abstract}
This aim of this research to suggest organization, motivation, and role of manager financial to performance managerial. The hypothesis of this research is that whether organization commitment, motivation and role of manager financial management positively affect and significant on the local government performance. Collecting data using primary data collection, is the questionnaire by using purposive sampling technique. Data obtained from manajer and used budgeting who work in Magelang District Government with number of questionnaires returns 119 respondents. Methods for analyzing the data using regression. The result of this study suggest organization commitment, motivation and role of manager financial management influence effect have a positive and significant performance managerial. This research is only a qualitative measure performance based on employee perceptions.
\end{abstract}

Key Words: organization commitment, motivation, the role of manager financial management, managerial performance

\section{PENDAHULUAN}

Reformasi pengelolan keuangan daerah telah digulirkan oleh pemerintah pusat, yang merupakan langkah maju khususnya dalam menata sistem pemerintahannya. Yang memberikan bukti bahwa pemerintah telah memberikan kewenangan secara nyata dan bertanggung jawab kepada daerah, dalam mengelola keuangan daerah yang hasilnya dapat diorientasikan pada masyarakatnya dalam rangka peningkatan kesejahteraan dan pemberdayaan daerah sehingga pengelolaan sumber- 
sumber daya daerah dapat dilakukan secara ekonomis, efisien, efektif, transparan, dan akuntabel.

Pemberian otonomi yang luas dan desentralisasi kepada kabupaten dan kota memberikan jalan bagi pemerintah daerah untuk melakukan pembaharuan dalam sistem pengelolaan keuangan daerah dan anggaran daerah. Dalam pengelolaan keuangan daerah, pemerintah daerah dituntut untuk melakukan pengelolaan keuangan daerah yang berorientasi pada kepentingan publik (public oriented) (Mardiasmo, 2002). Anggaran Pendapatan dan Belanja Daerah (APBD) merupakan salah satu alat untuk meningkatkan pelayanan publik dan kesejahteraan masyarakat sesuai dengan tujuan otonomi daerah yang luas nyata dan bertanggung jawab. Keuangan daerah harus dikelola dengan baik agar semua hak dan kewajiban daerah yang dapat dinilai dengan uang dapat dimanfaatkan semaksimal mungkin untuk kepentingan daerah (Putri 2010)

Pemberlakuan UU No 22 tahun 1999 tentang pemerintah daerah dan UU No 25 tahun 1999 tentang otonomi daerah dan desentralisasi fiscal. Yang kemudian dalam perkembangannya diperbaharui dengan UU Nomor 32 Tahun 2004 tentang pemerintah daerah dan UU Nomor 33 tentang perimbangan keuangan antara pusat dan daerah, yang membawa perubahan dalam hubungan tata pemerintah dan hubungan keuangan, sekaligus membawa perubahan penting dalam pengelolaan anggaran daerah (Pilipus, 2009). Perubahan yang mendasar pada pengelolaan keuangan daerah menuntut adanya perubahan dalam paradigma dan prinsip-prinsip keuangan daerah.

Sumber daya manusia salah satu indikator terpenting dalam pencapaian suatu tujuan, baik secara perorangan maupun kelompok sumber daya manusia sangat dibutuhkan untuk penggerak jalannya kegiatan usaha dalam pemerintahan maupun organisasi. Untuk itu setiap pemerintah maupun organisasi perlu mengatur, mengawasi dan memperhatikan keberadaan karyawannya sebagai usaha peningkatkan kinerja yang lebih baik. Penerapan sistem penilaian kinerja diperlukan dalam suatu organisasi yaitu untuk mengetahui hasil yang diperoleh karyawannya dalam bekerja. Kinerja adalah gambaran pencapaian pelaksanaan suatu kegiatan atau program atau kebijaksanaan dalam mewujudkan sasaran, tujuan, misi dan visi organisasi (Bastian 2006). Jadi untuk mengetahui kinerja karyawan sangatlah penting bagi organisasi maupun karyawan itu sendiri.

Komitmen mencakup keterlibatan kerja. Hal ini disebabkan karena antara keterlibatan kerja dengan komitmen organisasi sangat erat hubungannya. Keterlibatan kerja sebagai derajat kemauan untuk menyatukan dirinya dengan pekerjaan, menginvestasikan waktu, kemampuan dan energinya untuk pekerjaan, dan menganggap pekerjaannya sebagai bagian utama dari kehidupannya (Mardiana dalam Rachmawati 2009). Namun demikian, keberlangsungan kerja karyawan juga 
dipengaruhi oleh motivasi, yang dapat dicerminkan dari perilaku karyawan itu sendiri. Agar perilaku karyawan sesuai dengan tujuan organisasi, maka harus ada perpaduan antara motivasi akan pemenuhan kebutuhan mereka sendiri dan permintaan organisasi.

Berdasarkan uraian tersebut, peneliti mengembangkan dari penelitian sebelumnya yaitu dengan acuan penelitian Putri (2010) tentang Pengaruh Komitmen Organisasional dan Peran Manajer Pengelolaan Keuangan Daerah terhadap Kinerja Manajerial Satuan Kerja Perangkat Daerah. Hal yang membedakan penelitian ini dengan penelitian sebelumnya yaitu penambahan satu variabel independen yaitu motivasi kerja karena motivasi merupakan dorongan diri untuk melakukan sesuatu sehingga berdampak besar terhadap tujuan yang ingin dicapai. Dampak positif dari motivasi tersebut yaitu terlaksananya tujuan yang diharapkan oleh suatu organisasi, namun dapat dampak negatifnya yaitu pegawai akan merasa bergantung atas pengharapan akan penghargaan dari kinerjanya.

\section{KOMITMEN ORGANISASI DAN KINERJA MANAJERIAL SATUAN KERJA PERANGKAT DAERAH}

Komitmen organisasi merupakan sifat hubungan antara individu dengan organisasi kerja, dimana individu mempunyai keyakinan diri terhadap nilai-nilai dan tujuan organisasi kerja, adanya kerelaan untuk menggunakan usahanya secara sungguh-sungguh demi kepentingan organisasi kerja serta mempunyai keinginan yang kuat untuk tetap menjadi bagian dari organisasi kerja (Zainuddin, 2009). Dalam hal ini individu mengidentifikasikan dirinya pada suatu organisasi tertentu tempat individu bekerja dan berharap untuk menjadi anggota organisasi kerja guna turut merealisasikan tujuan-tujuan organisasi kerja.

Mowday (dalam Zainuddin, 2009) mendefinisikan komitmen organisasi adalah sebagai kekuatan yang relatif dari individu dalam mengidentifikasikan keterlibatan dirinya kedalam bagian organisasi. Hal ini dapat ditandai dengan tiga hal, yaitu:

a. Penerimaan terhadap nilai-nilai dan tujuan organisasi.

b. Kesiapan dan kesedian untuk berusaha dengan sungguh-sungguh atas nama organisasi.

c. Keinginan untuk mempertahankan keanggotaan didalam organisasi (menjadi bagian dari organisasi).

Keterkaitan karyawan terhadap organisasi tempatnya bekerja dikenal dengan istilah komitmen organisasi. Yang menjadi indikator kinerja salah satunya diperlukannya adanya komitmen dalam berorganisasi. Karyawan yang berkomitmen tinggi akan menghasilkan kinerja yang optimal. 
Sehingga organisasi dituntut untuk memiliki karyawan yang mempunyai komitmen tinggi.

Penelitian Putri (2010) tentang pengaruh komitmen organisasional dan peran manajer pengelolaan keuangan daerah terhadap kinerja manajerial satuan kerja perangkat daerah menunjukkan secara signifikan ada pengaruh komitmen organisasi, terhadap kinerja perangkat daerah di kabupaten Tegal. Penelitian Rachmawati (2009), menyatakan dalam kesimpulannya bahwa, komitmen organisasi berpengaruh positif terhadap kinerja karyawan bagian umum sekretariat daerah Pemerintah Daerah Kabupaten Sukoharjo.

Berdasarkan uraian tersebut, dapat dirumuskan hipotesis berikut:

$\mathrm{H}_{1}=$ Komitmen organisasi memiliki pengaruh positif dan signifikan terhadap kinerja manajerial satuan kerja perangkat daerah

\section{MOTIVASI KERJA DAN KINERJA MANAJERIAL SATUAN KERJA PERANGKAT DAERAH}

Robbins (2006) mendefinisikan motivasi sebagai kesediaan untuk mengeluarkan tingkat upaya yang tinggi ke arah tujuan-tujuan organisasi, yang dikondisikan oleh kemampuan upaya itu untuk memenuhi sesuatu kebutuhan individual. Menurut Sukanto dan Handoko (2000) motivasi didefinisikan keadaan dalam pribadi seseorang yang mendorong keinginan individu untuk melakukan kegiatan-kegiatan tertentu guna mencapai suatu tujuan.

Maslow (1984), telah mengembangkan suatu teori motivasi manusia. Konsep teorinya menjelaskan suatu hirarki kebutuhan yang menunjukkan lima tingkatan keinginan dan kebutuhan manusia. Kebutuhan dapat didefinisikan sebagai suatu kesenjangan atau pertentangan yang dialami antara satu kenyataan dengan dorongan yang ada dalam diri. Apabila pegawai kebutuhannya tidak terpenuhi maka pegawai tersebut akan menunjukkan perilaku kecewa. Sebaliknya, jika kebutuhannya terpenuhi maka pegawai tersebut akan memperlihatkan perilaku yang gembira sebagai manifestasi dari rasa puasnya. Abraham Maslow (1984 dalam Sukanto dan Handoko, 200o) mengemukakan bahwa hierarki kebutuhan manusia adalah sebagai berikut:

1. Kebutuhan fisiologis, yaitu kebutuhan untuk makan, minum, perlindungan fisik, bernapas, seksual. Kebutuhan ini merupakan kebutuhan tingkat terendah atau disebut pula sebagai kebutuhan yang paling dasar

2. Kebutuhan rasa aman, yaitu kebutuhan akan perlindungan diri dari ancaman, bahaya, pertentangan, dan lingkungan hidp 
3. Kebutuhan untuk rasa memiliki (sosial), yaitu kebutuhan untuk diterima oleh kelompok, berafiliasi, berinteraksi, dan kebutuhan untuk mencintai serta dicintai

4. Kebutuhan akan harga diri, yaitu kebutuhan untuk dihormati dan dihargai oleh orang lain

5. Kebutuhan untuk mengaktualisasikan diri, yaitu kebutuhan untuk menggunakan kemampuan, skill dan potensi. Kebutuhan untuk berpendapat dengan mengemukakan ide-ide, gagasan dan kritik terhadap sesuatu.

Motivasi yang ada pada seseorang akan mewujudkan suatu perilaku yang diarahkan pada tujuan mencapai sasaran kepuasan. Jadi, motivasi bukanlah sesuatu yang dapat diamati, tetapi adalah hal yang dapat disimpulkan adanya karena sesuatu perilaku yang tampak (Sukanto dan Hani 200o). Motivasi pada karyawan akan terdorong untuk berbuat semaksimal mungkin dalam melaksanakan tugasnya, dan mereka meyakini bahwa dengan keberhasilan organisasi mencapai tujuan dan berbagai sasarannya, maka kepentingan-kepentingan pribadinya akan terpelihara pula (Sukmawati dan Susanto, 2001 dalam Rachmawati 2009). Jadi, dengan adanya motivasi pada pekerja instansi terkait akan mempengaruhi kinerja yang dicapainya.

Penelitian Nasir (2009) tentang Hubungan anggaran partisipasi, kecukupan anggaran, komitmen organisasi, motivasi dan kinerja manajerial dengan model persamaan struktural. Hasilnya menunjukkan motivasi berpengaruh positif terhadap kinerja manejerial, penelitian Nasir (2009) diperkuat Penelitian Rachmawati (2009) menyatakan dalam kesimpulannya yang menunjukkan bahwa motivasi kerja berpengaruh positif terhadap kinerja pada pemda Kabupaten Sukoharjo.

Berdasarkan Uraian tersebut, dapat dirumuskan sebagai berikut:

$\mathrm{H} 2$ = Motivasi kerja memiliki pengaruh positif dan signifikan terhadap kinerja manajerial satuan kerja perangkat daerah

\section{PERAN MANAJER PENGELOLAAN KEUANGAN DAERAH DAN KINERJA MANAJERIAL SATUAN KERJA PERANGKAT DAERAH}

Manajer adalah orang yang bertanggung jawab atas hasil kerja satu orang atau lebih dalam suatu organisasi. Keterkaitan akan peran manajer dengan hasil kerja dapat terlihat dari terorganisirnya suatu hasil kerja. Mintzberg 1973 (dalam Schermerhorn 2000) menjelaskan bahwa tugas manajer sehari-hari mencangkup tiga peran yang harus dilakukan dengan baik, yang dapat yaitu: 
1. Peran interpersonal. Dalam hal ini seorang manajer harus dapat memainkan peran sebagai forehead, leader dan liaison (penghubung)

2. Peran Informasional. Dalam hal ini seorang manajer harus dapat memainkan perannya sebagai monitor, pemberi informasi dan sebagai spokesperson

3. Peran pengambil keputusan. Peran ini, manajer digambarkan sebagai entrepreneur, disturbance handle, resources allocator dan negotiator.

Peran menunjukkan partisipasi seseorang dalam mewujudkan tujuan organisasi. Peran manajerial Pengelola Keuangan Daerah menunjukkan tercapainya mekanisme penyelenggaraan pemerintahan yang efisien dan efektif. Desentralisasi memberikan kesempatan Pengelola Keuangan Daerah untuk mendorong kreatifitas Pengelola Keuangan Daerah. Individu yang terlibat dan diberi tanggungjawab dalam penyusunan anggaran akan bekerja lebih keras untuk mencapai tujuan, sehingga kinerja organisasi akan semakin tinggi (Rohman, 2008). Peran manajer pengelolaan keuangan daerah yaitu mengorganisasikan dan mengelola sumber-sumber daya dan kekayaan yang ada di daerah untuk dapat mencapai tujuan yang ditetapkan. Oleh karena itu, peran manajer pengelolaan keuangan daerah sangat penting dalam mewujudkan kinerja setiap SKPD.

Penelitian Tuasikal 2007 (dalam Putri 2010) pengaruh pemahaman sistem akuntansi, pengelolaan keuangan daerah terhadap kinerja satuan kerja perangkat daerah. Secara parsial pengelolaan keuangan berpengaruh terhadap kinerja satuan kerja perangkat daerah. Penelitian Rohman (2009) Pengaruh implementasi sistem akuntansi, pengelolaan keuangan daerah terhadap fungsi pengawasan dan kinerja pemerintah daerah, menunjukkan bahwa pengelolaan keuangan daerah berpengaruh terhadap kinerja Pemerintah Daerah.

Berdasarkan uraian tersebut, dapat dirumuskan hipotesis sebagai berikut:

$\mathrm{H}_{3}$ = Peran manajer pengelolaan keuangan daerah memiliki pengaruh positif dan signifikan terhadap kinerja manajerial satuan kerja perangkat daerah

\section{METODOLOGI PENELITIAN}

\section{A. Populasi dan Sampel}

Populasi dalam penelitian ini adalah para pegawai yang bekerja di SKPD pada Pemerintah Daerah Kabupaten Magelang. Alasan pemilihan daerah Magelang sebagai lokasi penelitian yaitu daerah Magelang merupakan salah satu pemerintah daerah yang telah melaksanakan kewenangan pemerintah 
pada tingkat kabupaten, sebagaimana yang tertuang dalam pasal 14 Undang-Undang nomor 32 tahun 2004

Sampel dalam penelitian ini adalah tingkat di bawah kepala SKPD yang bertindak selaku kuasa pengguna anggaran pada pemerintah Kabupaten Magelang. Pengguna dan kuasa pengguna anggaran/barang dipegang oleh pejabat structural tertinggi dalam SKPD sehingga bertanggung jawab dan yang mengambil kebijakan-kebijakan pada unit kerjanya masing-masing. Pemilihan sampel penelitian ini didasarkan pada metode purposive sampling, dimana sampel dipilih berdasarkan kriteria tertentu. Responden penelitian adalah kuasa dan pengguna anggaran pada SKPD di Pemerintah Daerah Kabupaten Magelang. Pejabat pada Pemerintah Daerah Kabupaten Magelang bekerja sebagai sekretaris dinas/badan, wakil direktur, kepala bagian, kepala sub bagian, kepala bidang, kepala sub bidang dan kepala seksi yang dianggap mampu untuk menggambarkan kinerja dari tiap sekretaris daerah, dinas-dinas dan lembaga teknis daerah secara keseluruhan.

\section{B. Data Penelitian}

Sumber data penelitian ini adalah data primer yang berasal dari jawaban responden atas beberapa pertanyaan yang diajukan peneliti melalui kuesioner yang dibagikan kepada manajer atau pimpinan setingkat dengan kepala bagian, kepala seksi, kepala sub bagian pada Dinas, Badan dan Lembaga Teknis Daerah di Kabupaten Magelang. Pemilihan Dinas, Badan dan Lembaga Teknis Daerah. Teknik pengumpulan data menggunakan metode kuesioner dan studi pustaka. Metode kuesioner dilakukan dengan membuat suatu daftar pertanyaan yang akan disebar untuk diisi oleh responden

\section{Variabel Penelitian dan Definisi Operasional Variabel}

1) Kinerja Manajerial

Kinerja Manajerial merupakan kinerja manajer dalam kegiatan manajerial yang meliputi perencanaan, investigasi, pengkoordinasian, evaluasi, pengawasan, pengaturan staff, negosiasi, dan perwakilan (Mahoney et al.1963 dalam kurniawan 2007).

Kinerja manajerial satuan kerja perangkat daerah merupakan variabel terikat (dependent variable), Untuk mengukur variabel ini, peneliti menggunakan instrument yang terdiri dari 9 item pernyataan dari Mahoney et al., 1965 (dalam Putri, 2010). Setiap responden diminta untuk menilai kinerjanya masing-masing dengan memilih skala 1-7. Skala 1-2 untuk kinerja dibawah rata-rata, 3-5 kinerja rata-rata dan 6-7 untuk kinerja diatas rata-rata. 
2) Komitmen organisasi

Komitmen organisasi merupakan sifat hubungan antara individu dengan organisasi kerja, dimana individu mempunyai keyakinan diri terhadap nilai-nilai dan tujuan organisasi kerja, adanya kerelaan untuk menggunakan usahanya secara sungguh-sungguh demi kepentingan organisasi kerja serta mempunyai keinginan yang kuat untuk tetap menjadi bagian dari organisasi kerja. (Zainuddin, 2009).

Komitmen organisasi merupakan variabel bebas (independent variable). Variabel komitmen organisasi diukur dengan menggunakan 7 pernyataan dengan menggunakan instrumen yang digunakan oleh Mowday et al. (1979) dan dimodifikasi oleh Dwianasari, 2004 ( dalam Putri, 2010). Variabel komitmen organisasi diukur dengan skala 7 poin.

3) Motivasi kerja

Motivasi merupakan daya dorong bagi seseorang untuk memberikan kontribusi yang sebesar mungkin demi keberhasilan organisasi mencapai tujuannya. (Siagian, 2002).

Motivasi kerja merupakan variabel bebas (independent variable). Variabel motivasi kerja diukur dengan 7 skala poin instrumen yang digunakan (Lowler, 1977 dalam Soetrisno, 2010).

4) Peran Manajer Pengelolaan Kuangan Daerah

Peran manajer pengelolaan keuangan adalah aktivitas manajemen yang berkesinambungan dengan strategi perencanaan dan pengendalian dalam keuangan (Halim dalam Putri, 2010). Aktivitas dalam hal ini, antara lain perencanaan tujuan dasar dan sasaran; perencanaan operasional; penganggaran; pengendalian dan pengukuran; dan pelaporan serta analisis

Peran manajer merupakan variabel bebas (variable independent).. Variabel peran manajer pengelolaan keuangan daerah diukur dengan Skala 7 poin. Dengan menggunakan instrument Mintzberg (1973) dalam Rohman (2008)

\section{Analisis Data}

1) Uji Validitas

Uji validitas adalah untuk mengetahui sah tidaknya instrumen kuisioner yang digunakan dalam pengumpulan data. Uji validitas dilakukan dengan korelasi bivariate antara masing-masing skor indikator dengan total skor konstruk. Uji signifikansi dilakukan dengan membandingkan rhitung dengan nilai rtabel untuk degree of freedom $(\mathrm{df})=\mathrm{n}-2$, adalah jumlah sempel dan $\mathrm{k}$ adalah jumlah konstruk dengan alpha 0,05. Bandingkan jika rhitung lebih besar dari rtabel dan nilai rtabel positif maka butir pertanyaan dikatakan valid.(Ghozali, 2009). 
2) Uji Reliabilitas

Suatu kuesioner dikatakan handal atau reliabel jika jawaban seseorang terhadap pertanyaan adalah konsisten atau stabil dari waktu ke waktu. Uji Reliabilitas dimaksudkan untuk menguji konsistensi kuesioner dalam mengukur suatu konstruk yang sama atau stabilitas kuesioner jika digunakan dari waktu ke waktu (Ghozali, 2009). Uji reliabilitas dilakukan dengan metode internal consistency. Kriteria yang digunakan dalam uji ini adalah One Shot, artinya satu kali pengukuran saja dan kemudian hasilnya dibandingkan dengan pertanyaan lainnya atau dengan kata lain mengukur korelasi antar jawaban pertanyaan. Statistical Product and Service Solution (SPSS) memberikan fasilitas untuk mengukur reliabilitas dengan uji statistik Cronbach Alpha $(\alpha)$. Jika nilai koefisien alpha lebih besar dari o,6o maka disimpulkan bahwa intrumen penelitian tersebut handal atau reliabel.

\section{E. Uji Hipotesis (Analisis Regeresi Berganda)}

Pengujian hipotesis dilakukan dengan menggunakan model analisis regresi berganda. Motode ini digunakan untuk mengetahui besarnya pengaruh variabel independen terhadap dependen (Ghozali, 2009). Menghubungkan satu variabel dependen yang dalam penelitian ini yaitu kinerja manajerial, dan variabel independen yaitu, komitmen, motivasi dan peran manajer pengelolaan keuangan daerah.

Persamaan regresinya adalah:

$$
\begin{aligned}
& Y=\beta_{0}+\beta_{1} X_{1}+\beta_{2} X_{2}+\beta_{3} X_{3}+e \\
& Y=\text { kinerja manajerial } \\
& \beta o=\text { intersep } \\
& \beta_{1}, \beta_{2}, \beta_{3}=\text { koefisien regresi } \\
& X_{1}=\text { komitmen organisasi } \\
& X_{2}=\text { motivasi kerja } \\
& X_{3}=\text { peran manajer pengelolaan keuangan daerah }
\end{aligned}
$$

Sementara itu, langkah-langkah untuk menguji pengaruh variabel independen, yaitu komitmen, motivasi, dan peran manajer pengelolaan keuangan daerah dilakukan dengan uji simultan dan uji parsial.

\section{HASIL DAN PEMBAHASAN}

\section{A. Analisis Regresi}

Analisis statistik yang digunakan dalam penelitian ini yaitu regresi berganda. Berikut ini adalah uraian hasil pengujian regresi berganda dan output table pengujian dengan menggunakan bantuan program SPSS versi 
17. Berdasarkan tabel 1 maka persamaan regresi yang terbentuk pada uji regresi ini adalah:

$$
\text { Kinerja Manajerial }=1.765+0.159 \mathrm{X}_{1}+0.227 \mathrm{X}_{2}+0.304 \mathrm{X}_{3}+\mathrm{e}
$$

Dari persamaan tersebut, dapat diketahui bahwa variabel bebas yang paling berpengaruh adalah variabel peran manajer pengelolaan keuangan daerah dengan koefisien 0.304. Kemudian diikuti oleh variabel motivasi kerja dengan koefisien $\mathbf{0 . 2 2 7}$ dan komitmen organisasional dengan koefisien 0.159 .

Tabel 1.

\section{Hasil Analisis Regresi}

\begin{tabular}{|c|c|c|c|c|c|}
\hline \multirow[b]{2}{*}{ Model } & \multicolumn{2}{|c|}{$\begin{array}{c}\text { Unstandardized } \\
\text { Coefficients }\end{array}$} & \multirow{2}{*}{$\begin{array}{c}\begin{array}{c}\text { Standardize } \\
\mathrm{d} \\
\text { Coefficients }\end{array} \\
\text { Beta }\end{array}$} & \multirow[b]{2}{*}{$\mathrm{T}$} & \multirow[b]{2}{*}{ Sig. } \\
\hline & $\mathrm{B}$ & Std. Error & & & \\
\hline 1 (Constant) & 1.765 & .518 & & 3.410 & 001 \\
\hline Komitmen & .159 & .077 & 179 & 2.057 & .042 \\
\hline $\begin{array}{l}\text { pengelolaan } \\
\text { keuangan }\end{array}$ & .304 & .076 & $\cdot 371$ & 3.977 & .000 \\
\hline $\begin{array}{l}\text { daerah } \\
\text { Motivasi }\end{array}$ & .227 & .101 & .212 & 2.246 & .027 \\
\hline
\end{tabular}

Sumber: Data primer diolah, 2011

\section{1) Pengujian Hipotesis Pertama, Pengaruh Komitmen Organisasional terhadap Kinerja Manajerial ( H1 )}

Hasil pengujian hipotesis pertama $\left(\mathrm{H}_{1}\right)$ yang menyebutkan Komitmen organisasional memiliki pengaruh positif dan signifikan dengan kinerja manajerial dikonfirmasi pada tabel 1 . Tabel 1 menunjukkan bahwa nilai koefisien regresi variabel komitmen orgasasional (X1) adalah o,159 dan nilai thitung 2,057. Nilai koefisien regresi ini signifikan pada tingkat signifikansi 0,05 dengan $p$ value sebesar 0,042. Hasil ini dipertegas dengan hasil perhitungan nilai thitung dan tabel. Nilai tabel pada taraf signifikansi 5\% dan df (derajat kebebasan) n-k-1 = 103 adalah 1,983. Dengan demikian, nilai thitung 2,057 $>$ ttabel 1,983. Hasil pengujian ini menginterpretasikan bahwa variabel komitmen organisaional berpengaruh positif dan signifikan terhadap kinerja manajerial pada taraf signifikansi $5 \%$ atau dengan kata lain $\mathrm{H}_{1}$ diterima. 


\section{2) Pengujian Hipotesis Kadua, Pengaruh Motivasi Kerja terhadap Kinerja Manajerial ( H2 )}

Hasil pengujian hipotesis kedua $\left(\mathrm{H}_{2}\right)$ yang menyebutkan bahwa motivasi kerja berpengaruh positif dan signifikan terhadap kinerja manajerial dikonfirmasi pada tabel 1, ditunjukkan bahwa nilai koefisien regresi variabel motivasi $\left(\mathrm{X}_{2}\right)$ adalah 0,227 dan nilai thitung 2,246. Nilai koefisien regresi ini signifikan pada tingkat signifikansi 0,05 dengan $p$ value sebesar 0,027 . Hasil ini dipertegas dengan hasil perhitungan nilai thitung dan tabel. Nilai $t^{\text {tabel }}$ pada taraf signifikansi $5 \%$ dan df (derajat kebebasan) $n-k-1=103$ adalah 1,983. Dengan demikian, nilai thitung 2,246 $>$ tabel 1,983 Hasil pengujian ini menginterpretasikan bahwa variabel motivasi berpengaruh positif dan signifikan terhadap kinerja manajerial pada taraf signifikansi $5 \%$ atau dengan kata lain $\mathrm{H}_{2}$ diterima.

\section{3) Pengujian Hipotesis Ketiga, Pengaruh Peran Manajer Pengelolaan Keuangan Daerah terhadap Kinerja Manajerial ( H3 )}

Hasil pengujian hipotesis kedua $\left(\mathrm{H}_{3}\right)$ yang menyebutkan bahwa peran manajer pengelolaan keuangan daerah berpengaruh positif dan signifikan terhadap kinerja manajerial dikonfirmasi pada tabel 1. Ditunjukkan bahwa nilai koefisien regresi variabel peran manajer pengelolaan keuangan daerah $\left(\mathrm{X}_{3}\right)$ adalah o,304 dan nilai thitung 3,977. Nilai koefisien regresi ini signifikan pada tingkat signifikansi 0,05 dengan $p$ value sebesar o,ooo. Hasil ini dipertegas dengan hasil perhitungan nilai thitung dan ttabel. Nilai ttabel pada taraf signifikansi $5 \%$ dan $\mathrm{df}$ (derajat kebebasan) n-k-1 = 103 adalah 1,983. Dengan demikian, nilai thitung 3,977 > tabel 1,983 Hasil pengujian ini menginterpretasikan bahwa variabel peran manajer pengelolaan keuangan daerah berpengaruh positif dan signifikan terhadap kinerja manajerial pada taraf signifikansi $5 \%$ atau dengan kata lain $\mathrm{H}_{3}$ diterima.

\section{4) Pengaruh Komitmen Organisasional terhadap Kinerja Manajerial}

Hasil hipotesis pertama $\left(\mathrm{H}_{1}\right)$ menyatakan bahwa komitmen organisasional berpengaruh positif dan signifikan terhadap kinerja manajerial satuan kerja perangkat daerah, diterima. Hasil ini menunjukkan semakin tinggi komitmen yang dimiliki responden maka kinerja manajerial semakin baik. Sehingga dapat disimpulkann adanya hubungan antara komitmen organisasi dengan kinerja manajerial aparat Pemerintah Daerah Magelang. Komitmen organisasi merupakan sifat hubungan antara individu dengan organisasi kerja, dimana individu mempunyai keyakinan diri terhadap nilai-nilai dan tujuan organisasi kerja. Seorang aparat pemerintah yang memiliki komitmen tinggi terhadap organisasinya maka dia akan merasa memiliki organisasi tersebut dan mempunyai keinginan untuk memberikan 
kontribusinya yang terbaik dalam memajukan organisasinya itu. Hal ini konsisten dengan penelitian Putri (2010), Trisnaningsih (2007) yang menunjukkan bahwa komitmen organisasional berpengaruh terhadap kinerja manajer instansi pemerintah, namun tidak sesuai dengan Warino (2009) yang menyatakan komitmen organisasi tidak pengaruh terhadap kinerja Satuan Kerja Perangkat Daerah.

\section{5) Pengaruh Motivasi Kerja Terhadap Kinerja Manajerial}

Hasil hipotesis kedua ( $\left.\mathrm{H}_{2}\right)$ menyatakan bahwa motivasi kerja berpengaruh positif dan signifikan terhadap kinerja manajerial satuan kerja perangkat daerah, diterima. Hal ini menunjukkan semakin tinggi motivasi kerja yang dimiliki responden maka kinerja manajerial semakin baik. Sehingga dapat disimpulkan bahwa adanya hubungan antara motivasi kerja dengan kinerja manajerial aparat Pemerintah Daerah Magelang.

Motivasi merupakan dorongan agar seseorang berkeinginan untuk melakukan kegiatan-kegiatan tertentu guna mencapai suatu tujuan. Penelitian ini sesuai dengan teori harapan yang menyatakan adalah kuatnya kecenderungan untuk bertindak dalam suatu cara tertentu bergantung pada kekuatan suatu penghargaan bahwa tindakan itu akan diikuti oleh suatu keluaran tertentu dan pada daya tarik dari keluaran tersebut bagi individu itu. Hal ini konsisten dengan penelitian Rachmawati (2009) dan yang menunjukkan bahwa motivasi kerja berpengaruh terhadap kinerja manajer instansi pemerintah, namun tidak sesuai dengan Soetrisno (2010) yang menyatakan motivasi kerja tidak berpengaruh signifikan terhadap kinerja manajerial.

\section{6) Pengaruh Peran Manajer Pengelolaan Keuangan Daerah}

Hasil hipotesis ketiga $\left(\mathrm{H}_{3}\right)$ menyatakan bahwa peran manajer pengelolaan keuangan daerah berpengaruh positif dan signifikan terhadap kinerja manajerial satuan kerja perangkat daerah. Hal ini menunjukkan bahwa adanya hubungan antara peran manajer dengan kinerja manajerial. Sehingga dapat disimpulkan peran manajer pengelolaan keuangan daerah yang tinggi dapat meningkatkan kinerja manajerial satuan kerja perangkat daerah di Pemerintahan Kabupaten Magelang. Hal ini konsisten dengan penelitian Tuasikal (2007) dan Putri (2009) yang menunjukkan bahwa peran manajer pengelolaan keuangan daerah berpengaruh terhadap kinerja manajer instansi pemerintah.

Peran manajer merupakan keterlibatan manajer dalam memotivasi, memberi pengawasan, keputusan, perencanaan kepada karyawannya guna pencapain tujuan organisasi. Hal ini mengindikasikan bahwa adanya suatu peran yang dilakukan oleh pejabat pengelola keuangan 
(kuasa dan pengguna anggaran/barang) untuk menunjukkan kinerja manajerial yang baik pada masing-masing SKPD. Peran yang dimainkan oleh para pengelola keuangan seperti peran interpersonal, peran informasi dan peran pengambilan keputusan juga dapat berpengaruh kepada pemerintah daerah. Dengan manajer memiliki peran tersebut, mendorong para pengelola keuangan untuk melaksanakan tujuan yang telah ditetapkan oleh organisasi pemerintah daerah.

Penelitian terdahulu mengenai Pengaruh Komitmen Organisasional Dan Peran Manajer Pengelolaan Keuangan Daerah terhadap Kinerja Manajerial Satuan Kerja Perangkat Daerah di Kabupaten Tegal. Hasilnya menunjukkan bahwa di dalam organisasi pemerintah daerah kabupaten Tegal, adanya hal yang positif terhadap pelaksanaan kewenangan Pemda, UU No 32 Tahun 2004 yang diharuskan mempunyai sistem pengelolaan daerah yang berorientasi terhadap publik. Hal ini terlihat dari pengaruh komitmen, dan peran manajer pengelolaan keuangan daerah yang menyatakan positif dan signifikan, sehingga dapat diimplikasikan bahwa dengan mempunyai komitmen yang tinggi para kuasa dan pengguna anggaran dapat menghasilkan kinerja manajerial yang maksimal.

Peneliti mengembangkan dari penelitian Putri (2010) yang menambahkan variabel indepen yaitu motivasi, yaitu menjadi Pengaruh Komitmen Organisasi, Motivasi Kerja Dan Peran Manajer Pengelolaan Keuangan Daerah Terhadap Kinerja Manajerial SKPD Di Kabupaten Magelang. Hasil yang didapat dalam hubungan penerapan terhadap Peraturan UU No 32 Tahun 2004 adalah positif, yaitu adanya pengaruh komitmen organisasi, motivasi kerja dan peran manajer pengelolaan keuangan daerah yang signifikan terhadap kinerja manajerial SKPD Pemerintahan Daerah di Kabupaten Magelang.

Hal ini dapat dilihat dari hasil kuesioner, yang menunjukkan selain komitmen terhadap organisasi pemerintah, para kuasa dan pengguna anggaran pemerintah daerah juga mempunyai motivasi dalam pemenuhan kewajibannya. Manajer pengelolaan keuangan pemerintah daerah dalam hal ini adalah para kuasa dan pengguna anggaran merupakan pegawai yang mempunyai ikatan terhadap organisasinya yaitu jalur birokrasi yang telah ditentukan memungkinkan mereka untuk dapat berkomitmen terhadap organisasi pemerintahannya, namun pada kenyataanya para kuasa dan pengguna anggaran tersebut mempunyai dorongan lain untuk dapat memaksimalkan kinerjanya, seperti adanya penghargaan untuk dirinya sendiri dalam konteks kepuasan dalam menghasilkan kinerja yang maksimal, adanya penghargaan yang didapat dari dari atasan, kenaikan jabatan atas prestasi yang didapatnya.

Sehingga dapat disimpulkan bahwa dengan adanya komitmen organisasi, motivasi kerja dan peran manajer (kuasa dan pengguna 
anggaran) didalam SKPD pemerintah daerah akan berdampak positif atau meningkatkan kinerja manajerial pada SKPD kabupatern Magelang.

\section{SIMPULAN}

Berdasarkan hasil penelitian maka dapat diambil kesimpulan sebagai berikut:

1. Komitmen organisasional, motivasi kerja dan peran manajer pengelolaan keuangan secara simultan berpengaruh positif dan signifikan terhadap kinerja manajerial satuan kerja perangkat daerah di Kabupaten Magelang

2. Secara parsial, komitmen organisasional berpengaruh positif dan signifikan terhadap kinerja manajerial, artinya semakin tinggi komitmen yang dimiliki oleh satuan kerja terkait maka akan tercapai kinerja manajerial yang diinginkan.

3. Motivasi berpengaruh positif dan signifikan terhadap kinerja manajerial, artinya semakin tinggi motivasi yang dimiliki oleh satuan kerja terkait maka kinerja manajerial semakin baik.

4. Peran manajer pengelolaan keuangan daerah berpengaruh positif dan siginifikan terhadap kinerja, Artinya peran manajer pengelolaan keuangan daerah yang tinggi dapat meningkatkan kinerja manajerial satuan kerja perangkat daerah.

\section{SARAN}

1. Penelitian selanjutnya disarankan untuk meneliti pengaruh variabelvariabel lain yang belum termasuk dalam model regresi pada penelitian ini seperti variabel kepemimpinan, tehnologi informasi, struktur budaya.

2. Penelitian selanjutnya disarankan dalam meneliti kinerja manajerial dalam suatu organisasi sebaiknya ditunjang dengan data kuantitatif antara lain menghitung pencapaian kinerja yang terdapat pada Laporan Akuntabilitas Kinerja Instansi Pemerintah.

\section{DAFTAR PUSTAKA}

Bastian, Indra. 2006. Akuntansi Sektor Publik di Indonesia. Yogyakarta

Ghozali, Imam. 2009. Aplikasi Analisis Multivariate dengan Program SPSS. Semarang: Badan Penerbit Universitas Diponegoro.

Handoko, Hani 200o. Dasar-dasar Manajemen, Produksi dan Operasi. Yogyakarta: BPFE-Yogyakarta 
Hermaningsih. 2009. Pengaruh Partisipasi dalam Penganggaran dan peran Manajerial Pengelola Keuangan Daerah terhadap Kinerja Pemerintah Daerah. Skripsi. Semarang: Universitas Diponegoro.

Kuntjoro, Zainuddin Sri. 2009. "Komitmen organisasi”.(Online), (http://epsikologi.com). Diakses tanggal 18 Maret 2011.

Kurniawan, Heppy. 2007. Pengaruh Desentralisasi dan Komitmen Organisasi sebagai Variabel Moderating dalam Hubungan antara Partisipasi Penyusunan Anggaran dengan Kinerja manajerial. Skripsi: Universitas Muhammadiayah Magelang.

Mardiasmo. 2002. Akuntansi Sektor Publik. Yogyakarta:Penerbit andi.

Martono, Heri. 2009. Pengaruh Kompetensi dan Motivasi Pembimbing Klinik terhadap Kinerja Pembimbing praktek klinik di RSUD Kabupaten Sragen. Tesis. Surakarta: PascasarjanaUniversitas Sebelas Maret.

Nasir, Muhammad. 2009. Hubungan anggaran partisipasi, kecukupan anggaran, komitmen organisasi, motivasi dan kinerja manajerial dengan model persamaan structural. Media Riset Akuntansi, Auditing dan Informasi. Vol.9; 57-73

Octavia, Diyah. 2009. Pengaruh Partisipasi Anggaran, Gaya Kepemimpinan dan Komitmen Organisasi terhadap Kinerja Manajerial pada PT POS Indonesia (Persero) Medan. Skripsi. Medan: Univesitas Sumatra Utara.

Petra Digital Collection. 2009. Motode Penelitian (Online),(www.google.com/metode-penelitian-populasi-sampel), diakses 11 Agustuszo11.

Putri, Natalia. 2010. Pengaruh Komitmen Organisasional dan Peran Manajer Pengelolaan Keuangan Daerah terhadap Kinerja Manajerial Satuan Kerja Perangkat Daerah. Skripsi. Semarang: Universitas Diponegoro.

Rachmawati, Shinta. 2009. Pengaruh Komitmen Organisasi, Motivasi Kerja, dan Gaya Kepemimpinan terhadap Kinerja Karyawan Bidang Keuangan pada Pemda Kabupaten Sukoharjo. Skripsi. Surakarta: Universitas Muhammadiyah Surakarta.

Ramandei, Pilipus. 2009. Pengaruh Karakteristik Sasaran Anggaran dan System Pengendalian Intern terhadap Kinerja Manajerial Aparat Pemerintah. Tesis. Semarang:Pascasarjana UNDIP.

Republik Indonesia. Undang-Undang Nomor 32 tahun 2004 tentang Pemerintah Daerah. direktorat Jenderal Otonomi Daerah. Jakarta.

Robbins, Stephen. 2006. Perilaku Organisasi. Alih Bahasa: Benyamin Molan. Edisi kesepuluh. Penerbit PT. Indeks, kelompok Gramedia, Jakarta

Rohman, Abdul. 2009. Pengaruh Implementasi Sistem Akuntansi, Pengelolaan Keuangan Daerah terhadap Fungsi Pengawasan dan Kinerja Pemerintah. Jurnal Akuntansi Dan Bisnis. Vol 9; 21-32.

Schermerhon, John. 2005. Manajemen. Andi, wiley \& Sons. 
Soetrisno. 2010. Pengaruh Partisipasi, Motivasi dan Pelimpahan Wewenang dalam Penyusunan Anggaran terhadap Kinerja Manajerial. Tesis. Semarang: Pascasarjana Universitas Diponegoro.

Sugiono. 2008. "Pembaharuan Tata kelola Keuangan Daerah". Bunga Rampai Keuangan Daerah. http://serba-serbi-keuangan-daerah.com. Diakses tanggal 18 Maret 2011.

Sukanto \& Hani. 200o. Organisasi Perusahaan. Yogyakarta: BPEE.

Supriyono, 2002. Sistem Pengendalian Manajemen. Yogyakarta: BPFE.

Tausikal, Askam. 2008. Pengaruh Pengawasan, Pemahaman Sistem Akuntansi Keuangan dan Pengelolaan Keuangan terhadap Kinerja Unit Satuan Kerta Pemerintah Daerah. finance and banking journal. Vol 10.

Trisnaningsih, Tri. 2007. Independensi Auditor dan Komitmen Organisasi sebagai Mediasi Pengaruh Pemahaman Good Governance, Gaya Kepemimpinan dan Budaya Organisasi terhadap Kinerja Auditor. SNA $X$. Jawa Timur.

Warisno. 2009. Faktor-faktor yang Mempengaruhi Kinerja Satuan Kerja Perangkat Daerah (SKPD) di lingkungan Daerah Provinsi Jambi. Tesis. Medan: Pasca Sarjana Universitas Sumatra Utara. 